Article

\title{
Assessment of Resident Happiness under Uncertainty of Economic Policies: Empirical Evidences from China
}

\author{
Zhigang Ouyang ${ }^{1}$, Fengyu Liu ${ }^{1, *}$, Ge Zhai ${ }^{2}$ and Svitlana Bilan ${ }^{3, *}$ \\ 1 School of Finance, Zhongnan University of Economics and Law, Wuhan 430073, China; \\ Z0004325@zuel.edu.cn \\ 2 Bartlett School of Planning, University College London, London WC1H 0NN, UK; uczlgz3@ucl.ac.uk \\ 3 Faculty of Administration and Social Sciences, University of Economics and Innovation in Lublin, \\ 20-209 Lublin, Poland \\ * Correspondence: fengyu@stu.zuel.edu.cn (F.L.); s.bilan@prz.edu.pl (S.B.)
}

Received: 10 August 2020; Accepted: 2 September 2020; Published: 6 September 2020

\begin{abstract}
The main aim of sustainable development is to increase the quality of life and resident happiness as the latter is one of the most important indicators for the assessment of quality of life. However, due to the uncertainty of economic policies, it will not only have a direct impact on resident well-being but may also indirectly affect resident well-being through specific channels. The economic policies are aimed at the achievement of sustainable development, therefore it is very important to investigate the influences of the uncertainty of economic policies on resident happiness. This allows to assess the sustainability of policies in terms of their inputs to the quality of life. The direct impact of economic policy uncertainty on resident well-being and the mediating effects of household asset allocation and the expectation on the above influencing relationship were analyzed based on the uncertainty index of China's economic policies and households database of China Family Panel Studies (CFPS) during the period 2010-2018, so as to clarify the complete path of economic policy uncertainty affecting resident happiness. Results show that the uncertainty of economic policy significantly reduces resident happiness. In the context of the uncertainty of economic policies, families can relieve such negative impacts as an increasing proportion of financial assets in their total assets. However, decreases in asset shares for household consumer goods and future expectation obviously lower resident happiness. The research conclusions provide important input in research on the influences of the uncertainty of economic policy on the quality of life and offer new evidences for the development of "happiness economics".
\end{abstract}

Keywords: uncertainty of economic policies; sustainability; quality of life; residents' happiness; asset allocation; expectation

\section{Introduction}

Influenced by the continuously intensifying Sino-US trade war and the spread of COVID-19 since the second half of 2019, uncertainty factors in economic policies have been increasing gradually. To decrease or eliminate the adverse impacts of these sudden events, the government of China adopted a series of economic countermeasures. These economic countermeasures produce positive effects in a short period. On the other hand, they increase uncertainty factors in economic policies and thereby influence various aspects of society and have an impact on long-term sustainable development goals.

Sustainable development includes many economic, social and environmental aspects that are significant [1-3]. However, if one had to choose only one indicator showing the progress of the sustainable development of a country, it would be difficult to decide what indicator it should be. Traditionally, in global statistics, GDP per capita is considered the most important indicator of a 
country's achieved economic welfare; however, this indicator does not reflect all the important dimensions of sustainable development [4]. Happiness is viewed as the important measure to assess subjective well-being (SWB). In 2012, the United Nations (UN) published the first World Happiness Report, which covered various world countries. Subsequently, the UN published the World Happiness Report every year. Nowadays, the World Happiness Report has become an authoritative reference to evaluate happiness level in countries around the world and it has been widely accepted by the international society. With economic development, countries pay more attention to economic development quality and wealth is not a decisive factor of happiness [5]. Ban Ki-moon, the former UN Secretary General, once mentioned that humans achieve the called "progresses" in blind pursuit of economic indexes at the sacrifice of something that shall be cherished. Recently, social and livelihood issues have attracted more and more attention in China, which has increased resident happiness accordingly. In this context, studying various factors that influence happiness is of more significance.

Uncertainty is an important concept in economics. Existing academic studies on uncertainty mainly concentrated in macroeconomic uncertainty [6], environmental uncertainty [7], financing uncertainty [8], cash flow uncertainty [9], income and expenditure uncertainty [10], and so on. With the development of economic policy uncertainty (EPU) index in recent years, most studies concerning uncertainty have focused on EPU. It has become the primary component of uncertainty studies. Based on literature review, it finds that there is a lot of research on the relationship between happiness and economics in academia. Most of the existing studies focus on the relationship between happiness and economic growth or income, but there are rare studies about the influences of EPU on households. As the basic participant of social life, residents are not only the typical representative of microeconomic activities, but also an important carrier of the effect of economic policies. Happiness is the "barometer" that reflects the life quality of residents. As economic policies should contribute to sustainable development, it is very important to investigate the influences of the uncertainty of economic policies on resident happiness. It does not only enrich the relevant research of economic policy uncertainty, but also provides a new development for the research on the relationship between happiness and economics, and allows to assess the sustainability of policies in terms of their inputs to quality of life by scrutinizing the influence of the uncertainty of economic policies on resident's happiness. In addition, it provides a useful reference for the government to formulate economic policies, families to choose economic behavior, and society to provide economic services. This study attempted to address this issue by applying the EPU index of China constructed by Huang and Luk [11] and the households' database of China Family Panel Studies (CFPS) during the period 2010-2018. Moreover, the influencing mechanism of EPU on resident happiness was investigated.

In this study, Chinese households were chosen as samples for the three following reasons. Firstly, China is undergoing the key stage of economic restructuring and updating and it is faced with the influence of various uncertainty factors at home and abroad. Secondly, China often makes quicker responses to various emergency events and adopts more specific economic measures. Thirdly, China has a big population and the research objects are more representative [12]. Studying the influences of EPU on resident happiness not only can provide the governments of different countries some references in formulating economic policies and improve residents' happiness, but also can help residents to adjust economic activities and psychological state and improve their life quality and happiness level, thus enabling to share the fruits from global economic development and social progresses [13].

The remainder of this study is organized as follows. Section 2 presents the literature review and research hypotheses; based on the review of existing literatures and research conclusions, some research hypotheses were proposed. Section 3 introduces research methods, constructs an empirical model for the proposed hypotheses, and describes data source. Section 4 analyzes the results for the testing of the proposed research hypotheses. Section 5 discusses the results. Section 6 concludes and develops policy implications. 


\section{Literature Review and Research Hypotheses}

\subsection{Economic Policy Uncertainty and Resident Happiness}

Existing studies concerning EPU mainly focus on the influences of EPU on macroeconomic market indexes and microeconomic individual activities. Leduc and Liu [14], Baker et al. [15], $\mathrm{Xu}$ and Wang [16] investigated the macroeconomic effect of applying the VAR (Vector autoregressive) model and the DSGE (Dynamic Stochastic General Equilibrium) model to EPU. They found that EPU had a negative impact linked to the increase in unemployment rate and lowered commodity price, shrinking investments and output level and an increase in social inflation rate. In addition, EPU caused a downturn of the US stock market and it was considered as one of the main reasons for the economic recession in the United States $[17,18]$.

At the micro level, the influences of the EPU mainly concentrate in the range of business operation and the activities of financial institutions. EPU increases the cash holdings of enterprises [19,20], lowers the leverage ratio of enterprises [21], relieves the dynamic regulation of the capital structure of enterprises [22], and inhibits the investment behavior of enterprises [23,24]. For financial institutions, EPU decreases bank credit [25-27]. When EPU increases, investment funds will increase the proportion of liquid assets and decrease the proportion of shareholding for preventive motivation and market timing motivation [28]. Few scholars have discussed influences of EPU on household's asset allocation and found that the EPU decreased the proportion of household risk assets in the total assets [29].

Based on the literature review, it is clear that under EPU conditions, economic entities generally adopt more conservative economic measures and the economic behavior of households focus on preventive ones. EPU exerts negative impacts at both the macroeconomics and microeconomic levels. Due to the general correlation between economic entities [30], as an important index to measure the psychological state and life quality of residents, happiness might decline to some extent due to EPU. At present, there are rare academic studies that discuss the influences of the uncertainty of economic policies on resident happiness directly. $\mathrm{Li}$ [31] investigated the influences of uncertainty on resident happiness from the perspective of uncertainty prevention and concluded that uncertainty prevention generally improved resident happiness. Considering the promotion of uncertainty prevention as a measure to increase resident happiness, EPU is used to measure uncertainty. Based on the above analysis, a research hypothesis was proposed:

\section{Hypothesis 1 (H1). EPU lowers Chinese residents' happiness.}

\subsection{Economic Policy Uncertainty, Asset Allocation and Resident Happiness}

There are few theories about the influences of EPU on happiness through a household's asset allocation. Some similar studies have discussed the influencing mechanism of uncertainty on happiness from the perspectives of consumption and savings [32]. According to the steady theory of SWB, the resident happiness is not only related with specific demographic statistics and the character traits of households but is also influenced by positive and negative events in daily life. Under normal conditions, the steady life state of family which is formed in the long period may generate a relatively stable happiness level. Resident happiness might deviate from the original state and further lose the stability when a family faces uncertainty in internal and external environments or impacts from a special life event [33].

From the perspective of the consumption level, households cannot adjust their previous consumption habits and consumption level timely and accurately when there are uncertainty factors in the external environment, thus influencing resident happiness [34]. For example, a household may be unable to maintain the previous consumption habit and living standards when one member is unemployed. As a result, resident happiness declines. Such negative impacts might be durable and profound [35]. In view of savings, according to the theory of preventive savings, due to risk aversion the households choose to create savings to prevent the negative impacts of uncertainty factors on 
their consumption level in the future. Since household's savings and consumption have a certain trade-off relation, changes in the households' savings level may influence resident happiness. Since the consumption level of residents is positively related with happiness [36-39], resident happiness declines due to the reduction of the consumption level. Based on the above analysis, the following hypothesis was proposed:

Hypothesis 2 (H2). EPU further influences resident happiness through household's asset allocation.

\subsection{Economic Policy Uncertainty, Expectation and Resident Happiness}

Expectation is a subjective inference of the possible outcomes in the future and other results caused by such outcomes. In modern economic theory, expectation occupies the core position in economic behavior. Each economic decision of the doer is affected by expectation factors to different extents, and it is the expectation of the future based on current economic variables. Keynes (1936) was the first to propose the expectation theory in his works of General Theory of Employment, Interests and Currency. He pointed out that uncertainty might cause decisive impacts on the economic behaviors of a households. His discussions on uncertainty and expectation are one of the most important contributions of the General Theory of Employment, Interests and Currency. This is the fundamental hypothesis for Keynes's theoretical system. Since expectation might influence resident happiness, EPU can influence resident happiness through expectation.

Expectation is an important social psychological state. Household members consciously or unconsciously make a subjective evaluation of society and individuals in the future, according to their previous life experiences and expectations of the future. Such evaluation can influence the psychology and behaviors of the household's members [40,41], thus influencing resident happiness. According to the theory of reasonable expectation [42-44], residents generate preventive motivations under uncertain conditions, which are influenced by the residents' expectations of the future. Uncertainty influences residents' expectations of the future. Li and Liu [45] divided expectation into future expectations, including assets, income conditions, working conditions and promotions, finding that the above expectation variables could all significantly increase resident happiness after various factors were controlled. The influence of expectation on happiness is mainly manifested as follows: people's expectation of the future can influence their feelings and emotional state [44] and residents can image future prospects according to their current life state. Positive expectation could improve resident happiness, while negative expectation often weakens resident happiness. Based on the above analysis, the following hypothesis was proposed:

Hypothesis 3 (H3). EPU inhibits resident happiness by lowering residents' expectation.

\section{Research Methods}

\subsection{Model Setting and Variable Declaration}

According to the study problem, EPU is a macroeconomic measurement index and can influence resident happiness to some extent. The resident is one of microeconomic individuals and its influence on EPU cannot be ignored. Therefore, EPU was used as an explanatory variable and resident happiness was used as the explained variable in the present study.

The ordered Probit model is often used in empirical studies with limited dependent variables and natural ordering. Since the explained variable of happiness is an ordinal discrete structure and has five levels of limited orders, the research objects in the present study were explained by the Ordered Probit model with references to research methodology and results in previous literatures. The Ordered Probit model can be set as

$$
H A P_{i, t}=\alpha_{0}+\alpha_{1} E P U_{t-1}+\alpha_{2} \text { control }_{i, t}+\alpha_{3} \text { pro }_{i, t}+\varepsilon_{i, t}
$$


where the subscripts $i$ and $t$ are the individual and time dimensions, respectively. $H A P_{i, t}$ refers to the subjective happiness of a household member and it is expressed by five levels from 1 to 5 . $E P U_{t-1}$ denotes the EPU index of the previous year and control $l_{, t}$ are other characteristic variables of residents. To prevent estimation errors caused by regional differences, the original samples were divided according to provinces for fixed effect estimation and expressed by $p r o_{i, t}$. $\varepsilon_{i, t}$ refers to the other various random disturbance terms.

(1) Economic policy uncertainty $(E P U)$ : in this study, the China EPU index which was compiled by Huang and Luk [11] from the Hong Kong Baptist University was applied. This China EPU index was set up by searching relevant keywords in 10 representative newspapers in mainland China, including Beijing Youth Daily, Guangzhou Daily, Liberation Daily, People's Daily Overseas Edition, Shanghai Morning Post, Southern Urban Daily, Beijing News, Today Evening News, Wen Hui Daily and Yangcheng Evening News. Since the households' panel data used the annual data, the mean of the monthly data of EPU index divided by 100 was used as the EPU index of the current year. With considerations of endogenous problems, this study chose the China EPU index as the lag-phase I data, which were data in 2009, 2011, 2013, 2015 and 2017. The EPU index was calculated to be 1.259, 1.654, 1.409, 1.506 and 1.290, which presented a certain fluctuation trend.

(2) Happiness (HAP): psychologists tend to measure SWB by a direct measuring method, in which the well-being level, or known as the happiness level, is measured by ordinal selection indexes (e.g., 1, $2,3, \ldots)$ through question and answer (Q\&A). It is widely accepted to measure the happiness level of individuals by order number in the economic field. Currently, a questionnaire survey based on a big sample size is a relatively popular method to measure happiness in happiness economics [46], in which the happiness level of individuals is expressed by ordinal numbers. In the CFPS questionnaire of happiness, there is a question asking "How happy are you?". Five ordinal numbers from 1 to 5 were provided to express happiness satisfaction from low to high. In other words, " 1 " refers to very unhappy and " 5 " denotes very happy. In order to make the measurement of family happiness more accurate and representative, referring to previous literature [28,31], this paper uses the happiness level of the head of the household as an indicator to express the level of the household's happiness. According to a descriptive statistical analysis on household happiness in 2010, 2012, 2014, 2016 and 2018 based on CFPS, the average household's happiness level was calculated to be $3.747,3.287,3.778$, 3.623 and 4.025 in these five years, respectively. This also presents a certain fluctuation trend. It is easy to discover by comparing with the EPU index data that there is a certain negative correlation between happiness and EPU.

(3) Households asset allocation and expectation. In this study, the continuous investigation of micro level data of families of CFPS during the period 2010-2018 was applied. According to the household's asset classification in the original database, this study mainly discussed the variables related with the household's asset allocation: (1) financial asset (FIN), including cash, savings as deposit, stocks, funds, national debt, trust product and foreign exchange product; (2) house asset (HOU), including the house that the households live in and other houses under possession; (3) production and operation assets (PRO), including agricultural activities like the planting industry ("agriculture" in the narrow sense), forestry industry, animal husbandry, fishery industry and subsidiary businesses, as well as industry and commerce activities like individual operation and private enterprises; and (4) durable consumer goods $(C O N)$, including products which are worth of over CNY 1000 and more than 2 years of natural service life, such as automobiles, home appliances, furniture, jewelry and musical instruments. For the accurate measurement of the structure and proportion of households' asset allocation, the values of aforementioned households' assets divided by the total households' assets were used as the variables to measure the household's asset allocation.

For the variables related with expectation $(E X P)$, the following data were used as mediating variables according to the setting of the original database: "How are you confident about your future?" in the design of the CFPS questionnaire. Similar with the measurement of happiness, it is measured by 
numbers 1 5. Specifically, "1" denotes "not confident" and " 5 " refers to "very confident". This variable could be used to measure the household's expectation of the future.

Control variables (control): control variables included gender, age, square of age, marriage state, education years, politics state, health condition, type of registered permanent residence, working condition, social insurance, household income and households' assets. Among them, gender (GEN) values 1 for males and 0 for females. Age $(A G E)$ refers to the age of informants at the year of investigation and it was calculated by the integral age. The square of age $\left(A G E^{2}\right)$ was equal to age ${ }^{*}$ age/100. Marriage state $(P L O)$ values 1 for the married and 0 for the single. Education $(E D U)$ refers to number of years that residents have received education and it was calculated in integral years. Politics state (PLO) was 1 for members of Chinese Communist Party and 0 for others. Type of registered permanent residence (REG) is 1 for urban registration and 0 for rural registration. Working condition (WOR) is 1 for people with employment and 0 for the people without employment. Social insurance (GUR) is 1 for people with social insurance and 0 for people without social insurance. Household income (INC) and assets (ASS) are the natural logarithms of the total income and total assets of households in the year.

\subsection{Data Source and Descriptive Statistical Analysis}

In this study, data were collected from the China Family Panel Studies (CFPS) program organized by the Institute of Social Science Survey (ISSS) of Peking University. The CFPS program has gained support from many government sectors and many famous universities in China. Investigation data samples do not only have a wide coverage, good stability and strong representativeness, but also are panel data in continuous years which have been collected in recent years. Therefore, they have relatively high academic values. Since this study focuses on the relationship between EPU and resident happiness, EPU changes with time and its influences on resident happiness cannot be measured by simple cross-section data. On the other hand, panel data can assure the reliability of empirical results better. Therefore, the household's data of CFPS during the period 2010-2018 were chosen for the empirical study.

According to selection of variables and the study problem, a descriptive statistic was carried out using Stata 15, thus obtaining results of various variables of CFPS (Table 1).

Table 1. Descriptive statistics of variables.

\begin{tabular}{cccccc}
\hline Variables & $\mathbf{N}$ & Mean & Std & Min & Max \\
\hline EPU & 70,153 & 1.419 & 0.145 & 1.259 & 1.657 \\
HAP & 58,211 & 3.687 & 1.078 & 1 & 5 \\
FIN & 66,421 & 0.116 & 0.205 & 0 & 1 \\
HOU & 53,586 & 0.618 & 0.331 & 0 & 1 \\
PRO & 52,629 & 0.025 & 0.093 & 0 & 1 \\
CON & 51,777 & 0.103 & 0.183 & 0 & 1 \\
EXP & 58,153 & 3.802 & 1.115 & 1 & 5 \\
GEN & 59,877 & 0.593 & 0.491 & 0 & 1 \\
AGE & 60,003 & 51.487 & 14.022 & 16 & 110 \\
AGE & 60,003 & 28.475 & 14.794 & 2.56 & 121 \\
MAR & 70,143 & 0.742 & 0.437 & 0 & 1 \\
EDU & 57,849 & 7.013 & 4.719 & 0 & 22 \\
PLO & 60,472 & 0.097 & 0.296 & 0 & 1 \\
HEA & 59,993 & 3.085 & 1.306 & 1 & 5 \\
REG & 59,114 & 0.298 & 0.457 & 0 & 1 \\
WOR & 58,639 & 0.638 & 0.481 & 0 & 1 \\
GUR & 69,900 & 0.920 & 0.272 & 0 & 1 \\
INC & 63,105 & 10.133 & 1.365 & 0 & 16.156 \\
ASS & 65,745 & 12.014 & 1.600 & 0 & 18.199 \\
\hline
\end{tabular}

It is easy to observe that the mean EPU index of China during the sampling period of 2010-2018 was 1.419 , which was at a high level. In the samples, proportions of the FIN, HOU, PRO and CON 
in the total households' assets reflect the structure and quantity of the households' asset allocation. Proportions of the FIN, HOU, PRO and CON in the total households' assets were $11.6 \%, 61.8 \%, 2.5 \%$ and $10.3 \%$, respectively. $\mathrm{HOU}$ accounts for the highest proportion in the total households' assets. FIN and CON account for equal proportions, while PRO accounts for the lowest proportion. The mean expectation level of a household is 3.802, and it is at the above-average level. Logarithms of INC and ASS are 10.133 and 12.014, respectively. Household assets are higher than the household income, which conforms to the law of households' wealth accumulation. Descriptive statistics of other characteristic variables of households are not introduced in the present study due to the limited space of the article.

\section{Results Analysis}

\subsection{Basic Regression Analysis}

The influence of control variables on resident happiness before EPU is added in are listed in Columns (1)-(2) of Table 2. Influences of control variables on resident happiness after EPU is added in are shown in Columns (3)-(4) of Table 2. Among them, Columns (1) and (3) neglect the fixed effect of provinces, while Columns (2) and (4) controlled the fixed effect of provinces. According to regression results, EPU lowers resident happiness significantly under the $1 \%$ level, thus verifying Hypothesis 1.

Table 2. Model regression results of the impact of economic policy uncertainty on happiness.

\begin{tabular}{|c|c|c|c|c|}
\hline Variable & $\begin{array}{c}(1) \\
H A P\end{array}$ & $\begin{array}{c}(2) \\
H A P\end{array}$ & $\begin{array}{c}(3) \\
H A P\end{array}$ & $\begin{array}{l}(4) \\
H A P\end{array}$ \\
\hline EPU & & & $\begin{array}{c}-1.192^{* * * *} \\
(0.035)\end{array}$ & $\begin{array}{c}-1.248^{* * *} \\
(0.035)\end{array}$ \\
\hline GEN & $\begin{array}{c}-0.100^{* * *} \\
(0.011)\end{array}$ & $\begin{array}{c}-0.084^{* * *} \\
(0.011)\end{array}$ & $\begin{array}{c}-0.078^{* * * *} \\
(0.011)\end{array}$ & $\begin{array}{c}-0.058^{* * *} \\
(0.011)\end{array}$ \\
\hline$A G E$ & $\begin{array}{c}-0.022^{* * *} \\
(0.002)\end{array}$ & $\begin{array}{c}-0.024^{* * *} \\
(0.003)\end{array}$ & $\begin{array}{c}-0.027^{* * * *} \\
(0.003)\end{array}$ & $\begin{array}{c}-0.028^{* * *} \\
(0.003)\end{array}$ \\
\hline$A G E^{2}$ & $\begin{array}{c}0.036^{* * *} \\
(0.002)\end{array}$ & $\begin{array}{c}0.038^{* * *} \\
(0.003)\end{array}$ & $\begin{array}{c}0.040^{* * *} \\
(0.003)\end{array}$ & $\begin{array}{c}0.042^{* * * *} \\
(0.003)\end{array}$ \\
\hline$M A R$ & $\begin{array}{c}0.253^{* * *} \\
(0.016)\end{array}$ & $\begin{array}{c}0.244^{* * *} \\
(0.017)\end{array}$ & $\begin{array}{c}0.259^{* * *} \\
(0.017)\end{array}$ & $\begin{array}{c}0.249^{* * *} \\
(0.017)\end{array}$ \\
\hline$E D U$ & $\begin{array}{l}0.003^{* *} \\
(0.001)\end{array}$ & $\begin{array}{c}0.004^{* * *} \\
(0.001)\end{array}$ & $\begin{array}{c}0.005^{* * *} \\
(0.001)\end{array}$ & $\begin{array}{c}0.006^{* * *} \\
(0.001)\end{array}$ \\
\hline PLO & $\begin{array}{c}0.128^{* * *} \\
(0.020)\end{array}$ & $\begin{array}{c}0.126^{* * *} \\
(0.018)\end{array}$ & $\begin{array}{c}0.098^{* * *} \\
(0.019)\end{array}$ & $\begin{array}{c}0.094^{* * *} \\
(0.019)\end{array}$ \\
\hline$H E A$ & $\begin{array}{c}0.193^{* * *} \\
(0.004)\end{array}$ & $\begin{array}{c}0.191^{* * *} \\
(0.004)\end{array}$ & $\begin{array}{c}0.153^{* * *} \\
(0.004)\end{array}$ & $\begin{array}{c}0.149^{* * *} \\
(0.004)\end{array}$ \\
\hline$R E G$ & $\begin{array}{l}0.023 * \\
(0.013)\end{array}$ & $\begin{array}{c}0.015 \\
(0.013)\end{array}$ & $\begin{array}{c}0.020 \\
(0.012)\end{array}$ & $\begin{array}{c}0.009 \\
(0.013)\end{array}$ \\
\hline WOR & $\begin{array}{c}0.082^{* * *} \\
(0.012)\end{array}$ & $\begin{array}{c}0.081^{* * *} \\
(0.012)\end{array}$ & $\begin{array}{c}0.064^{* * *} \\
(0.012)\end{array}$ & $\begin{array}{c}0.062^{* * *} \\
(0.012)\end{array}$ \\
\hline GUR & $\begin{array}{c}0.120^{* * *} \\
(0.018)\end{array}$ & $\begin{array}{c}0.100^{* * *} \\
(0.018)\end{array}$ & $\begin{array}{c}0.125^{* * *} \\
(0.018)\end{array}$ & $\begin{array}{c}0.103^{* * *} \\
(0.019)\end{array}$ \\
\hline INC & $\begin{array}{c}0.039^{* * *} \\
(0.004)\end{array}$ & $\begin{array}{c}0.047^{* * *} \\
(0.004)\end{array}$ & $\begin{array}{c}0.052^{* * * *} \\
(0.004)\end{array}$ & $\begin{array}{c}0.062^{* * * *} \\
(0.004)\end{array}$ \\
\hline ASS & $\begin{array}{c}0.060 * * * \\
(0.004)\end{array}$ & $\begin{array}{c}0.070^{* * *} \\
(0.004)\end{array}$ & $\begin{array}{c}0.064^{* * *} \\
(0.004)\end{array}$ & $\begin{array}{c}0.075^{* * *} \\
(0.004)\end{array}$ \\
\hline pro & No & Yes & No & Yes \\
\hline$N$ & 47,123 & 47,121 & 47,123 & 47,121 \\
\hline Pseudo $R^{2}$ & 0.0293 & 0.0347 & 0.0381 & 0.0443 \\
\hline
\end{tabular}

Notes: ${ }^{*}, * *$, and ${ }^{* * *}$ indicate statistical significance at the $10 \%, 5 \%$, and $1 \%$ levels, respectively. $t$-Values reported in parentheses. 
Regression results of other control variables, except for the explanatory variable EPU, are basically consistent with expectation before setting. Specifically, females generally have a higher happiness assessment than males. The influence of age on happiness present U-shaped variations. The happiness of married residents is the highest. The regression coefficient of the happiness of members of the Chinese Communist Party is positive. The increase in education years usually means better development prospects, so the regression result of education years is significantly positive, and the level of the residents' happiness is higher. The improvement in social security level not only improves the security ability of residents, but also makes the residents have more psychological security. Therefore, the level of happiness of residents participating in social security is higher, and the regression result is also significantly positive. Urban residents generally show a higher happiness level than rural residents. In addition, good health conditions, fixed employment and increases in household income and assets can all significantly promote resident happiness.

\subsection{Machinability Analysis}

According to Hypothesis 2 and Hypothesis 3, EPU might influence resident happiness through asset allocation and the expectation channel. To verify these two hypotheses, the following mediating effect model was constructed by combining the Model (1):

$$
\begin{gathered}
Y_{i, t}=\beta_{0}+\beta_{1} E U_{t-1}+\beta_{2} \text { control }_{i, t}+\beta_{3} \text { pro }_{i, t}+\varepsilon_{i, t} \\
H A P_{i, t}=\gamma_{0}+\gamma_{1} E P U_{t-1}+\gamma_{2} Y_{i, t}+\gamma_{3} \text { control }_{i, t}+\gamma_{4} \text { pro }_{i, t}+\varepsilon_{i, t}
\end{gathered}
$$

Under the premise that $\alpha_{1}$ in the Model (1) is significantly, Models (2) and (3) were tested. $Y_{i, t}$ refers to the variable of asset allocation or expectation. If $\beta_{1}$ and $\gamma_{2}$ are significant, the mediating effect is verified as true.

According to Model (2), the influence of EPU on the mediating variables of asset allocation expectation are shown in Table 3. The selection of control variables is same as that in Table 2. Since the household's asset allocation is a proportional value within $[0,1]$ and it is censored, it was estimated with the Tobit model. Regression results are shown in Columns (1)-(4). EPU can increase the proportions of FIN and PRO in the total households' assets significantly, but it can inhibit $H O U$ and CON greatly. Column (5) discusses the influences of EPU on expectation. Since expectation is measured by the similar method of resident happiness, the Ordered Probit model can be applied for regression. According to regression results, EPU can significantly inhibit the expectation of the households' members of the future. These regression results are significant under the $1 \%$ level.

Table 3. Model regression results of the impact of economic policy uncertainty on intermediary variables.

\begin{tabular}{cccccc}
\hline \multirow{2}{*}{ Variable } & $\mathbf{( 1 )}$ & $\mathbf{( 2 )}$ & $\mathbf{( 3 )}$ & $\mathbf{( 4 )}$ & $\mathbf{( 5 )}$ \\
& $\mathbf{F I N}$ & $\mathbf{H O U}$ & $\mathbf{P R O}$ & $\mathbf{C O N}$ & $\boldsymbol{E X P}$ \\
\hline \multirow{2}{*}{ EPU } & $0.355^{* * *}$ & $-0.085^{* * *}$ & $0.100^{* * *}$ & $-0.172^{* * *}$ & $-0.301^{* * *}$ \\
& $(0.008)$ & $(0.011)$ & $(0.009)$ & $(0.006)$ & $(0.035)$ \\
\hline \multirow{2}{*}{ con } & $-0.298^{* * *}$ & $-0.816^{* * *}$ & $-0.505^{* * *}$ & $1.023^{* * *}$ & - \\
\hline Control & $(0.027)$ & $(0.037)$ & $(0.032)$ & $(0.019)$ & \\
\hline pro & Yes & Yes & Yes & Yes & Yes \\
\hline Yes & Yes & Yes & Yes & Yes \\
\hline Pseudo $R^{2}$ & 0.1862 & 0.3290 & 0.2473 & 0.4145 & 0.0265 \\
\hline *** indicate statistical significance at the $1 \%$ levels, respectively. $t$-Values reported in parentheses.
\end{tabular}




\subsection{Effects of EPU on Resident Happiness Based on Asset Allocation Channel and Expectation Channel}

To further study the influences of EPU on resident happiness through asset allocation expectation, a regression analysis of the above settings was carried out with the ordered Probit model based on data in Model (3) and Table 4. After other variables and provincial fixed effects were controlled, it can be seen from the regression that EPU can significantly lower resident happiness. Influences of EPU and the above variables on resident happiness after a household's asset allocation and expectation are added in and are shown in Columns (1)-(6). To prevent the model estimation errors caused by the missing variables, the above mediating variables and EPU are considered in Column (6). Results show that the influences of EPU on resident happiness are still significantly negative under the $1 \%$ level, thus proving the robustness and reliability of the conclusion. Influences of FIN, CON and expectation on resident happiness under EPU conditions are still significantly under the $1 \%$ level, while $H O U$ and $P R O$ are insignificant to resident happiness.

Table 4. Model regression results of economic policy uncertainty and intermediary variables on happiness.

\begin{tabular}{|c|c|c|c|c|c|c|}
\hline Variable & $\begin{array}{c}(1) \\
H A P\end{array}$ & $\begin{array}{c}(2) \\
H A P\end{array}$ & $\begin{array}{c}(3) \\
H A P\end{array}$ & $\begin{array}{c}(4) \\
H A P\end{array}$ & $\begin{array}{c}(5) \\
H A P\end{array}$ & $\begin{array}{c}(6) \\
H A P\end{array}$ \\
\hline$E P U$ & $\begin{array}{c}-1.288^{* * *} \\
(0.036)\end{array}$ & $\begin{array}{c}-1.527^{* * *} \\
(0.040)\end{array}$ & $\begin{array}{c}-1.880^{* * *} \\
(0.044)\end{array}$ & $\begin{array}{c}-1.824^{* * *} \\
(0.044)\end{array}$ & $\begin{array}{c}-1.262^{* * *} \\
(0.036)\end{array}$ & $\begin{array}{c}-1.356^{* * *} \\
(0.049)\end{array}$ \\
\hline FIN & $\begin{array}{c}0.295^{* * *} \\
(0.026)\end{array}$ & & & & & $\begin{array}{c}0.215^{* * *} \\
(0.042)\end{array}$ \\
\hline $\mathrm{HOU}$ & & $\begin{array}{c}-0.039 * \\
(0.020)\end{array}$ & & & & $\begin{array}{c}0.033 \\
(0.035) \\
\end{array}$ \\
\hline PRO & & & $\begin{array}{l}0.161 \text { ** } \\
(0.063)\end{array}$ & & & $\begin{array}{c}0.047 \\
(0.071)\end{array}$ \\
\hline CON & & & & $\begin{array}{c}0.284^{* * *} \\
(0.040)\end{array}$ & & $\begin{array}{c}0.168^{* * *} \\
(0.050)\end{array}$ \\
\hline$E X P$ & & & & & $\begin{array}{c}0.523^{* * *} \\
(0.006)\end{array}$ & $\begin{array}{c}0.565^{* * *} \\
(0.008)\end{array}$ \\
\hline pro & Yes & Yes & Yes & Yes & Yes & Yes \\
\hline$N$ & 47,014 & 38,016 & 36,899 & 36,855 & 46,974 & 33,362 \\
\hline Pseudo $R^{2}$ & 0.0452 & 0.0501 & 0.0540 & 0.0543 & 0.1289 & 0.1465 \\
\hline
\end{tabular}

Notes: ${ }^{* * *}$, and ${ }^{* * *}$ indicate statistical significance at the $10 \%, 5 \%$, and $1 \%$ levels, respectively. $t$-Values reported in parentheses.

\subsection{Heterogeneity Analysis}

To further study the influence of EPU on the happiness of different groups and individuals, the household members were divided into female and male families according to gender, married and single families according to marriage condition, rural and urban families according to type of registered permanent residence, and the youth, middle-age and the aged families according to the age structure. According to the division of the World Health Organization (WHO), the youth family $\leq 44$ years old; 45 years old $\leq$ middle-aged family $\leq 59$ years old; the aged family $\geq 60$ years old. Since the happiness level is measured by the ordinal number, the ordered Probit model was applied for estimation. Results are listed in Table 5.

According to the regression results, EPU can significantly inhibit the happiness of residents with different feature types. Specifically, the happiness levels of female families, married families and rural families declined more when EPU is increased compared to the male families, the single families and urban families, respectively. With respect to age structure, the happiness level of the youth family 
declined more under EPU conditions, followed by the middle-aged families. The happiness level of the aged families declined slightly. These results are all significant under the $1 \%$ level.

Table 5. Heterogeneity analysis of the impact of economic policy uncertainty on happiness.

\begin{tabular}{|c|c|c|c|c|c|c|c|c|c|}
\hline Variable & $\begin{array}{c}\text { HAP } \\
\text { WOMEN }\end{array}$ & $\begin{array}{l}\text { HAP } \\
\text { MAN }\end{array}$ & $\begin{array}{c}\text { HAP } \\
\text { UNMARRIED }\end{array}$ & $\begin{array}{c}\text { HAP } \\
\text { MARRIED }\end{array}$ & $\begin{array}{c}\text { HAP } \\
\text { RURAL }\end{array}$ & $\begin{array}{c}\text { HAP } \\
\text { URBAN }\end{array}$ & $\begin{array}{c}\text { HAP } \\
\text { YOUNG }\end{array}$ & $\begin{array}{c}\text { HAP } \\
\text { MIDDLE }\end{array}$ & $\begin{array}{l}H A P \\
O L D\end{array}$ \\
\hline$E P U$ & $\begin{array}{c}-1.275^{* * *} \\
(0.055)\end{array}$ & $\begin{array}{c}-1.235^{* * * *} \\
(0.046)\end{array}$ & $\begin{array}{c}-0.778^{* * *} \\
(0.102)\end{array}$ & $\begin{array}{c}-1.322 * * * \\
(0.038)\end{array}$ & $\begin{array}{c}-1.252^{* * *} \\
(0.042)\end{array}$ & $\begin{array}{c}-1.231^{* * *} \\
(0.066)\end{array}$ & $\begin{array}{c}-1.377^{* * *} \\
(0.062)\end{array}$ & $\begin{array}{c}-1.189 * * * \\
(0.056)\end{array}$ & $\begin{array}{c}-1.202 * * * \\
(0.070)\end{array}$ \\
\hline pro & Yes & Yes & Yes & Yes & Yes & Yes & Yes & Yes & Yes \\
\hline$N$ & 19,431 & 27,690 & 5687 & 41,434 & 32,993 & 14,128 & 14,783 & 18,735 & 13,603 \\
\hline Pseudo $R^{2}$ & 0.0419 & 0.0478 & 0.0551 & 0.0421 & 0.0413 & 0.0559 & 0.0473 & 0.0442 & 0.0404 \\
\hline
\end{tabular}

Notes: ${ }^{* * *}$ indicate statistical significance at the $1 \%$ levels, respectively. $t$-Values reported in parentheses.

\subsection{Robustness Test}

The robustness of the model and regression results was tested by the two following aspects. One was to re-estimate the setting model and the relevant variables by using the ordinary least square (OLS) model, thus obtaining regression results similar to the original estimations. Regression results are shown in Table 6. According to the tested regression results, the relationship between the EPU and resident happiness was consistent with the results in Tables 2 and 4 . The other was to make a regression analysis by replacing the China EPU index with the EPU index of the United States which was constructed by Baker et al. [15] due to the mutual influences between Chinese and American economic policies. The regression results were basically similar with the original estimation results, thus proving the stability of the model and the reliability of the regression results.

Table 6. Robustness test of the impact of economic policy uncertainty on happiness.

\begin{tabular}{|c|c|c|c|c|c|c|c|}
\hline Variable & $\begin{array}{c}(1) \\
H A P\end{array}$ & $\begin{array}{c}(2) \\
H A P\end{array}$ & $\begin{array}{c}(3) \\
H A P\end{array}$ & $\begin{array}{c}(4) \\
H A P\end{array}$ & $\begin{array}{c}(5) \\
H A P\end{array}$ & $\begin{array}{c}(6) \\
H A P\end{array}$ & $\begin{array}{c}(7) \\
H A P\end{array}$ \\
\hline$E P U$ & $\begin{array}{c}-1.187^{* * *} \\
(0.033)\end{array}$ & $\begin{array}{c}-1.223^{* * *} \\
(0.033)\end{array}$ & $\begin{array}{c}-1.419 * * * \\
(0.037)\end{array}$ & $\begin{array}{c}-1.749 * * * \\
(0.040)\end{array}$ & $\begin{array}{c}-1.695^{* * *} \\
(0.040)\end{array}$ & $\begin{array}{c}-1.051^{* * *} \\
(0.030)\end{array}$ & $\begin{array}{c}-1.075^{* * *} \\
(0.039)\end{array}$ \\
\hline FIN & & $\begin{array}{c}0.282^{* * * *} \\
(0.025)\end{array}$ & & & & & $\begin{array}{c}0.171^{* * *} \\
(0.034)\end{array}$ \\
\hline $\mathrm{HOU}$ & & & $\begin{array}{c}-0.044 \text { ** } \\
(0.019)\end{array}$ & & & & $\begin{array}{c}0.019 \\
(0.028)\end{array}$ \\
\hline$P R O$ & & & & $\begin{array}{c}0.155^{* * *} \\
(0.060)\end{array}$ & & & $\begin{array}{c}0.039 \\
(0.057) \\
\end{array}$ \\
\hline CON & & & & & $\begin{array}{c}0.260^{* * *} \\
(0.037)\end{array}$ & & $\begin{array}{c}0.126^{* * *} \\
(0.040)\end{array}$ \\
\hline$E X P$ & & & & & & $\begin{array}{c}0.437 * * * \\
(0.005)\end{array}$ & $\begin{array}{c}0.461^{* * *} \\
(0.006)\end{array}$ \\
\hline _con & $\begin{array}{c}3.490^{* * *} \\
(0.111)\end{array}$ & $\begin{array}{c}3.410^{* * *} \\
(0.111)\end{array}$ & $\begin{array}{c}3.910^{* * *} \\
(0.126)\end{array}$ & $\begin{array}{c}4.422 * * * \\
(0.130)\end{array}$ & $\begin{array}{c}4.151^{* * *} \\
(0.135)\end{array}$ & $\begin{array}{c}2.236^{* * *} \\
(0.098)\end{array}$ & $\begin{array}{c}1.927^{* * *} \\
(0.132)\end{array}$ \\
\hline pro & Yes & Yes & Yes & Yes & Yes & Yes & Yes \\
\hline$N$ & 47,121 & 47,014 & 38,016 & 36,899 & 36,855 & 46,974 & 33,362 \\
\hline$R^{2}$ & 0.1188 & 0.1212 & 0.1317 & 0.1413 & 0.1421 & 0.3070 & 0.3399 \\
\hline
\end{tabular}

Notes: ${ }^{* *}$, and ${ }^{* * *}$ indicate statistical significance at the $5 \%$, and $1 \%$ levels, respectively. $t$-Values reported in parentheses.

\section{Discussion}

According to regression in Table 2, EPU can significantly inhibit resident happiness. This conclusion proves the proposed Hypothesis 1: EPU lowers residents' happiness. This is a new discovery of this 
study. Previous studies about the influences of EPU on economic entities are mainly negative $[14,23,26]$. This conclusion is in good agreement with the results of other existing studies on EPU. Results which conform to previous studies were gained through a regression of influences of control variables on resident happiness [47-50]. Specifically, the influence coefficient of gender on happiness is negative. Females are easier to be satisfied since they eliminate pressures and they have lower social responsibility and pressure over survival.

The influence of the coefficient of age on happiness is positive and the square of the influences is negative. Generally speaking, youth have greater goals and motivations for striving, whereas aged people lead a quiet life and have no high requirements for living standards. As a result, for the aged residents it is easier to feel happy than for the young people, which in their turn are more prone to migration because of low well-being and dissatisfaction with life [51]. The middle-aged group bears a dual pressure of life and working, so that they often have a lower happiness level than the aged group.

The influence of marriage on happiness is positive. The married residents have a certain psychological stability and often have higher happiness. Political state, education years and type of registered permanent residence can all improve resident happiness. In China, the members of Chinese Communist Party generally represent a high-income group with stable employment and income, thus showing higher happiness. Residents with longer education years generally have better cultural accomplishment and individual development. Obviously, education background has positive effects on happiness. Urban residents generally possess better living conditions and more social insurance than rural residents, thus showing relatively higher happiness. In addition, good health conditions, stable employment, social insurance and increases in household income and assets mean that the individuals have better health and life insurances. All of these factors can significantly promote resident happiness.

The influencing path of EPU on resident happiness might be reflected by various aspects. In this study, it was found that EPU mainly influenced resident happiness through asset allocation and their expectations. It can be seen from the regression results in Table 3 that EPU has different effects on various household's asset allocations and expectations, and the regression results are very significant. This indicates that EPU might influence resident happiness through the above channels.

To further disclose the influencing mechanism and effect of EPU on resident happiness through the household's asset allocation and expectation, a regression analysis that used EPU, household's asset allocation and expectation as explanatory variables, and resident happiness as the explained variable, was carried out. The results are listed in Table 4. Firstly, the EPU changes the structure and proportions of the households' asset allocation and it influences resident happiness by increasing savings and lowering consumption. Since there is a positive relationship between households' consumption level and happiness [35-38], resident happiness declines accordingly. This further proves Leland's theory of precautionary saving from the perspective of an empirical study [52], and thereby proves the proposed Hypothesis 2. Secondly, EPU lowers residents' expectations about their future. This conforms to Keynes's (1936) discussion of the relationship between uncertainty and expectations. With the reduction of the expectation level, resident happiness declines [45], thus verifying the proposed Hypothesis 3 . Since changes of the proportion of HOU and PRO in total households' assets under EPU conditions influence resident happiness slightly, EPU cause no significant impacts on resident happiness through changes in the proportion of HOU and PRO in the total household's assets, even though it significantly influences changes in the proportions of $H O U$ and PRO.

Under EPU conditions, increased proportions of FIN and CON in total households' assets can significantly improve resident happiness. Although $H O U$ and $P R O$ can promote resident happiness to some extent, yet such promotion is not very great. FIN is an important component of household wealth. Since financing institutions and the market started and developed late in China, cash and deposits is a main FIN of Chinese households due to the influences of traditional culture. In China, households often possess a great amount of saving assets to cope with various sudden events and daily consumptions, which is called the "mystery of high savings" in the academic circle [53]. Residents' happiness is improved by the increasing proportion of FIN centered on savings in total households' 
assets. EPU means that there are some uncertainties in the external environment and risk factors in the market might increase. Possessing FIN not only brings residents a sense of psychological safety, but can also be used to buy daily necessities to meet their living needs and cope with various needs which may arise at any time in the future. In addition, FIN is also an important symbol of social wealth and positions of a household. As a result, an increasing proportion of FIN in the total households' assets can significantly improve resident happiness. In contrast to FIN, CON better reflects the attributes of consumer goods and it is the direct result and product of the residents' participation in consumption activities. Consumption meets people's assessment on commodity or services and increases the utility level of residents [38,54], thus enabling to significantly improve resident happiness [37,55]. Compared with FIN, CON generally has poor cash ability. Therefore, increasing proportion of $C O N$ in the total households' assets under EPU conditions can promote resident happiness less than FIN.

$\mathrm{HOU}$ accounts for the highest proportion in the total households' assets. Compared with other assets, $\mathrm{HOU}$ occupies a great deal of capital and has a long transaction period and poor liquidity. It is the typical real estate. HOU meets the living demands of residents. It is proven that residents with property rights of houses have higher happiness than tenants [56] and families with large houses have significantly higher happiness than families with small houses [57]. One study also pointed out that the living attributes of houses can improve resident happiness significantly, while the asset attribute of houses cannot [58]. These studies were investigated from the properties of houses, but did not reflect the structure of houses in the households' assets. Cai et al. [59] divided houses into consumptive houses and investment houses according to the functions and investigated influences of their proportions in the total households' assets on resident happiness. They found that in consumptive houses, households generally cannot produce income from investment, thus significantly lowering resident happiness. On the contrary, households in investment houses can easy sell their houses and receive considerable income, which meets the utility level of families. Hence, it can significantly improve resident happiness. In this study, most houses are for self-dwelling. Although houses meet the living requirements of families, they occupy a lot of households' assets, and households have low cash ability. Under EPU conditions, economic activities in market-like real estate transactions decrease significantly [60]. Hence, although resident happiness can be improved to some extent by increasing the proportion of $\mathrm{HOU}$ in the total households' asset under EPU conditions, such promotion is very small and the regression results are insignificant.

PRO mainly combines with the production and business activities of families and has a relatively high rate of return. Generally speaking, $P R O$ has a relatively stable income and it can bring families stable cash flows [61]. This cash flow can be used for not only for deposits, house buying and durable consumer goods, but also for further investment into production and business activities, thus enabling to improve resident happiness. Although the PRO of households can bring stable earnings under relatively stable economic operations, there is certain production and business risk when there is great uncertainty of economic policies and restraint by the external economic environment and industrial policies. Under this circumstance, PRO might suffer some losses. According to the prospect theory, ordinary families generally make stronger responses to loss than the equal scale of income [59,62], however, proper and fair income distribution is important too [63]. Therefore, although PRO has positive effects on resident happiness under EPU conditions, such effects are insignificant due to the uncertainties in benefits or loss of business assets.

Expectations are an important concept in economics. Although this study chose only one variable as the index to measure residents' expectations of the future, it is easy to find through literature review that the various expectations of household members are often closely correlated. Residents' expectations come from various aspects, including income, assets, job, social status, living conditions and so on. Different expectations generally reflect the residents' positive or negative attitudes toward their future [45]. At present, universal opinion and research results in the academic literature indicate that positive expectations can significantly promote resident happiness, while negative expectations may greatly lower resident happiness $[64,65]$. Expectations might influence residents' happiness more 
than the actual situation of families [66]. Households with an optimistic attitude generally have a higher happiness level. Moreover, positive expectations also increase households' supports to the social system and it is conducive to maintain social stability [67], which in return increases resident happiness. According to the regression results, the confidence degrees of households' members for the future (positive expectations) can significantly increase resident happiness. Such results are in line with other studies on well-being, which stress positive links between job satisfaction and overall well-being [68], subjective assessments of stability within the concept of holistic well-being [69], and the impact of the social system on the perception of well-being [70].

According to the regression results in Table 5, EPU can significantly inhibit the happiness of residents with different characteristics. Specifically, the happiness levels of female families, married families and rural families decrease more than male families, the singled families and urban families when EPU is increased, respectively. With respect to age structure, the happiness level of the youth family decreases mostly under EPU conditions, followed by that of the middle-aged families. The happiness level of the aged families decreases slightly. Under EPU conditions, female families, the married families, rural families and youth families show a less optimistic expectation of the future and they are more concerned more with economic policies. As a result, they are more sensitive to uncertainty factors in economic policies. In addition, the residents of these types can also adjust the types and quantities of households' asset structures through the asset allocation channel, thus significantly lowering resident happiness.

\section{Conclusions}

This study allowed us to assess the sustainability of economic policies in terms of their uncertainty effect on resident's happiness as the main measure of subjective well-being. Based on the China EPU index and the family database of CFPS during the period 2010-2018, this study not only investigated the influence of economic policy uncertainty (EPU) on resident happiness, but also further explored the effects of EPU on happiness through the household's asset allocation and expectations. Some major conclusions could be drawn.

Firstly, EPU significantly lowers resident happiness. Secondly, the EPU influences resident happiness through asset allocation and expectations channels. Finally, the inhibition effects of EPU on the happiness of residents with different characteristics vary. This is related with their different responses in asset allocation and expectation when facing with EPU.

This study not only provides a beneficial supplementation to the studies of influences of the EPU on families, but also offers new evidence for relevant studies on "happiness economics". The results of this study provide important policy implications for the government, families, social institutions and other economic agents. It provides important reference, how to formulate sustainable economic policies, choose economic behaviors and offer economic services to achieve long-term sustainable development goals of the country expressed by the increased residents' happiness.

As the monitor and important interferer of macroeconomic operation, the government shall keep the continuity and stability of economic policies during their formation, fully consider the impact of economic policies on different types of families, so as to introduce more targeted measures to improve the level of residents' happiness. As residents' happiness is an important indicator to measure the implementation effect of government economic policies, these targeted measures are more conducive to improving the level of social governance of the government. Families shall not only be concerned with changes of national economic policies during asset allocation, but also make a rational analysis on their own financial state and market trend, adjust proportions of various assets reasonably, keep a clear mind and calm judgment, comprehend the goal and potential meaning of government in formulating economic policies, and adjust their own expectations timely. In this way, resident happiness can benefit more from changes in household asset structure and expectation. Social enterprises and institutions shall publish an accurate interpretation of the government's economic policies timely to the social 
public, adjust industrial structure timely in accordance with economic policies, and provide a higher quality of products and services, aiming to improve residents' happiness continuously.

Nevertheless, this study has some limitations. There are many influencing paths of EPU on resident happiness. Limited by data accessibility, this study investigated these issues from the perspectives of household asset allocation and expectations. In future research, the other influencing paths of EPU on resident happiness shall be further expanded, including the impact of EPU on human development, following the findings obtained earlier [71].

Author Contributions: Conceptualization, Z.O. and F.L.; methodology, Z.O. and G.Z.; formal analysis, Z.O., F.L. and G.Z.; supervision, S.B.; writing - original draft preparation, Z.O. and F.L.; writing-review and editing, G.Z. and S.B. All authors have read and agreed to the published version of the manuscript.

Funding: This research was funded by National Natural Science Foundation of China (71973044), Academic and Technological Leaders Project of Major disciplines in Jiangxi Province (20182BCB22008), Medium and Long Term Research Project of Zhongnan University of Economics and Law (31510000049) and Postgraduate Scientific Research Innovation Project of Zhongnan University of Economics and Law (201810502).

Acknowledgments: In this section you can acknowledge any support given which is not covered by the author contribution or funding sections. This may include administrative and technical support, or donations in kind (e.g., materials used for experiments).

Conflicts of Interest: The authors declare no conflict of interest.

\section{References}

1. Morcillo-Bellido, J.; Prida-Romero, B. Sustainability is changing the way that we innovate in the energy sector through energy service companies (ESCO). DYNA 2018, 93, 246.

2. Buntak, K.; Kovaèiæ, M.; Mutavdžija, M. Internet of things and smart warehouses as the future of logistics. Teh. Glas. Tech. J. 2019, 13, 248-253. [CrossRef]

3. Strielkowski, W.; Ren, L.; Yao, S.; Rong, D.; Skare, M.; Streimikis, J. Renewable energy barriers and coping strategies: Evidence from the Baltic States. Sustain. Dev. 2019, 28, 352-367. [CrossRef]

4. Mori, K.; Christodoulou, A. Review of sustainability indices and indicators: Towards a new City Sustainability Index (CSI). Environ. Impact Assess. Rev. 2012, 32, 94-106. [CrossRef]

5. McCarthy, L. "There is no time for rest": Gendered CSR, sustainable development and the unpaid care work governance gap. Bus. Ethic. Eur. Rev. 2018, 27, 337-349. [CrossRef]

6. Wang, Y.Z.; Song, M. Macroeconomic uncertainty, demand for financing and corporate investment. Econ. Res. J. 2014, 49, 4-17.

7. Shen, H.H.; Yu, P.; Wu, L.S. State ownership, environment uncertainty and investment efficiency. Econ. Res. J. 2012, 47, 113-126.

8. Lian, Y.J.; Su, Z. Financial constraints, uncertainty and firms' investment efficiency. Manag. Rev. 2009, 21, $19-26$.

9. Liu, B.; Li, Z.S.; Wang, H.L.; Yang, J.Q. Cash flow uncertainty and corporate innovation. Econ. Res. J. 2017, $52,166-180$.

10. Luo, C.L. Uncertainty during economic transition and household consumption behavior in urban China. Econ. Res. J. 2004, 39, 100-106.

11. Huang, Y.; Luk, P. Measuring economic policy uncertainty in China. China Econ. Rev. 2020, 59, 1-18. [CrossRef]

12. Hernandez-Luna, M.; Robledo-Fava, R.; Fernandez-de-Cordoba, P.; Paredes, A.; Michinel, H.; Zaragoza, S. Use of statistical correlation for energy management in office premises adopting techniques of the industry 4.0. DYNA 2018, 93, 602-607.

13. Strotmann, H.; Jürgen, V.; Schmidt, M. Multinational companies: Can they foster well-being in the eyes of the poor? Results from an empirical case study. Int. J. Corp. Soc. Responsib. 2019, 4, 1-14. [CrossRef]

14. Leduc, S.; Liu, Z. Uncertainty shocks are aggregate demand shocks. J. Monet. Econ. 2016, 82, 20-35. [CrossRef]

15. Baker, S.R.; Bloom, N.; Davis, S.J. Measuring economic policy uncertainty. Q. J. Econ. 2016, 131, 1593-1636. [CrossRef] 
16. $\mathrm{Xu}, \mathrm{Z} . W . ;$ Wang, W.F. Does policy uncertainty drive Chinese aggregate fluctuations? Evidences and dynamic analysis. China Econ. Q. 2015, 18, 23-50.

17. Gertler, M.; Karadi, P. Monetary policy surprises, credit costs, and economic activity. Am. Econ. J. Macroecon. 2015, 7, 44-76. [CrossRef]

18. Ko, J.H.; Lee, C.M. International economic policy uncertainty and stock prices: Wavelet approach. Econ. Lett. 2015, 134, 118-122. [CrossRef]

19. Li, F.Y.; Shi, Y.D. Economic policy uncertainty and corporate cash holding strategy: Empirical research by using China economic policy uncertainty index. J. Manag. Sci. China 2016, 19, 157-170.

20. Gulen, H.; Ion, M. Political uncertainty and corporate investment. Rev. Financ. Stud. 2016, 29, 523-546. [CrossRef]

21. Zhang, G.L.; Han, J.L.; Pan, Z.Y.; Huang, H.Z. Economic policy uncertainty and capital: Structure choice evidence from China. Econ. Syst. 2015, 39, 439-457. [CrossRef]

22. Wang, C.Y.; Zhang, X.L.; Bao, H.N. Economic policy uncertainty, the dynamic adjustment of enterprises' capital structure and stabilizing leverage. China Ind. Econ. 2018, 12, 134-151.

23. Kang, W.; Lee, K.; Ratti, R.A. Economic policy uncertainty and firm-level investment. J. Macro. Econ. 2014, 39, 42-53. [CrossRef]

24. Zhang, C.S.; Liu, G.C. The investing and financing decision mechanism of the Chinese real sector: Economic uncertainty and the financial constraints perspective. Econ. Res. J. 2018, 53, 51-67.

25. Bordo, M.D.; Duca, J.V.; Koch, C. Economic policy uncertainty and the credit channel: Aggregate and bank level U.S. evidence over several decades. J. Financ. Stab. 2016, 26, 90-106. [CrossRef]

26. He, Z.; Niu, J. The effect of economic policy uncertainty on bank valuations. Appl. Econ. Lett. 2018, 25, 345-347. [CrossRef]

27. Hu, S.; Gong, D. Economic policy uncertainty, prudential regulation and bank lending. Financ. Res. Lett. 2019, 29, 373-378. [CrossRef]

28. Li, J.Y.; Li, H.; Gan, L. Household assets, debts and happiness: An explanation to happiness-income puzzle. Nankai Econ. Stud. 2015, 5, 3-23.

29. Liu, F.Y.; Zhao, Y.L.; He, F.M. Uncertainties in economic policies and allocation of family assets. Financ. Econ. Res. 2019, 34, 98-109.

30. Sangamuang, S. A graph-based algorithm for interpersonal ties clustering in signed networks. Tehnički Glasnik 2019, 13, 275-279. [CrossRef]

31. Li, H.J. Insurance against uncertainty and subjective well-being of city workers: Based on the counterfactual framework. Chin. J. Sociol. 2014, 34, 140-165.

32. Cummins, R.A. Subjective well-being, homeostatically protected mood and depression: A synthesis. J. Happiness Stud. 2010, 11, 1-17. [CrossRef]

33. Loewenstein, G.; Rabin, T.O. Projection bias in predicting future utility. Q. J. Econ. 2003, 118, 1209-1248. [CrossRef]

34. Clark, A.E.; Frijters, P.; Shields, M.A. Relative income, happiness, and utility: An explanation for the Easterlin paradox and other puzzles. J. Econ. Lit. 2008, 46, 95-144. [CrossRef]

35. Guven, C. Reversing the question: Does happiness affect consumption and savings behavior? J. Econ. Psychol. 2012, 33, 701-717. [CrossRef]

36. Hang, B. Gift spending and urban household consumption: An empirical study based on status seeking. Stat. Res. 2015, 32, 68-76.

37. Hu, R.H.; Sun, J.L. Can Consumption make us happy. Stat. Res. 2015, 32, 69-75.

38. Wang, Y.P. New development of happiness economics research. Econ. Perspect. 2017, 10, 130-146.

39. Wang, J.X. Residents' Need Satisfaction and Social Expectation. Jiangsu Soc. Sci. 2017, 1, 67-74.

40. Escadas, M.; Jalali, M.S.; Farhangmehr, M. Why bad feelings predict good behaviours: The role of positive and negative anticipated emotions on consumer ethical decision making. Bus. Ethics Eur. Rev. 2019, 28, 529-545. [CrossRef]

41. Muth, J.F. Rational expectations and the theory of price movements. Econometrica 1961, 29, 315-335. [CrossRef]

42. Lucas, R.E. Expectations and the neutrality of money. J. Econ. Theory 1972, 4, 103-124. [CrossRef]

43. Sargent, T.J.; Wallace, N. State ownership, environment uncertainty and investment efficiency. Econ. Res. J. 1976, 2, 169-183. 
44. Smith, D.; Rhiney, E. CSR commitments, perceptions of hypocrisy, and recovery. Int. J. Corp. Soc. Responsib. 2020, 5, 1-12. [CrossRef]

45. Li, L.; Liu, B. The impact of anticipation on happiness of urban residents in China. Nankai Econ. Stud. 2012, 4, 53-67.

46. Tian, G.Q.; Yang, L.Y. A Solution to the happiness-income puzzle: Theory and evidence. Econ. Res. J. 2006, 41, 4-15.

47. Stone, A.A.; Schwartz, J.E.; Broderick, J.E.; Deaton, A. A snapshot of the age distribution of psychological well-being in the United States. Proc. Natl. Acad. Sci. USA 2010, 107, 9985-9990. [CrossRef]

48. Ashkanasy, N.M. International Happiness: A Multilevel Perspective. Acad. Manag. Perspect. 2012, 25, $23-29$.

49. Mackerron, G. Happiness economics from 35000 feet. J. Econ. Surv. 2012, 26, 705-735. [CrossRef]

50. Asadullah, M.N.; Xiao, S.; Yeoh, E. Subjective well-being in China, 2005-2010: The role of relative income, gender, and location. China Econ. Rev. 2018, 48, 83-101. [CrossRef]

51. Mishchuk, H.; Roshchyk, I.; Sułkowska, J.; Vojtovič, S. Prospects of Assessing the Impact of External Student Migration on Restoring the Country's Intellectual Potential (Case Study of Ukraine). Econ. Sociol. 2019, 12, 209-219. [CrossRef]

52. Leland, H.E. Saving and uncertainty: The precautionary demand for saving. Q. J. Econ. 1968, 82, 465-473. [CrossRef]

53. Gan, L.; Zhao, N.B.; Sun, Y.Z. Income inequality, liquidity constraints and China's household savings rate. Econ. Res. J. 2018, 53, 34-50.

54. Dutt, A.K. Maturity, stagnation and consumer debt: A Steindlian approach. Metroeconomica 2006, 57, 339-364. [CrossRef]

55. Wang, B.Z.; Cheng, Z. Environmental perceptions, happiness and pro-environmental actions in China. Soc. Indic. Res. 2017, 132, 357-375. [CrossRef]

56. Morris, E.A. Is a fixer-upper actually a downer? Homeownership, gender, work on the home, and subjective well-being. Hous. Policy Debate 2018, 28, 342-367. [CrossRef]

57. Li, T.; Shi, Y.P.; Chen, B.K. Homeownership and happiness: Theory and evidence from China. Econ. Res. J. 2011, 9, 69-82.

58. Zhang, X.; Li, L.Y.; Chai, C.S.; Ma, S. Housing increases happiness: Investment attribute or residential attribute? J. Financ. Res. 2015, 10, 17-31.

59. Cai, R.F.; Xu, S.Y.; Guo, X.X.; Chen, P. Household asset allocation and subjective well-being: Empirical test based on CHFS data. Q. J. Financ. 2016, 10, 1-30.

60. Gholipour, H.F. The effects of economic policy and political uncertainties on economic activities. Res. Int. Bus. Financ. 2019, 48, 210-218. [CrossRef]

61. Li, T.; Chen, B.K. Real assets, wealth effect and household consumption: Analysis based on China household survey data. Econ. Res. J. 2014, 49, 62-75.

62. Kahneman, D.; Tversky, K.A. Prospect theory: An analysis of decision under risk. Econometrica 1979, 47, 263-292. [CrossRef]

63. Mishchuk, H.; Samoliuk, N.; Bilan, Y.; Streimikiene, D. Income inequality and its consequences within the framework of social justice. Probl. Ekorozw. 2018, 13, 131-138.

64. Wu, X.G. Income inequality and distributive justice: A comparative analysis of mainland China and Hong Kong. China Q. 2009, 200, 1033-1052. [CrossRef]

65. Yue, J.L.; Zhang, H.P. Income inequality perception, expectation and happiness: An empirical study based on the survey data of the 2017 welfare attitudes in Guangdong. J. Public Adm. 2018, 11, 100-119.

66. Kreidl, M. Perceptions of poverty and wealth in western and post-communist countries. Soc. Justice Res. 2000, 13, 151-176. [CrossRef]

67. Lu, J.T.; Ren, L.C.; Zhang, C.; Liang, M.S.; Stasiulis, N.; Streimikis, J. Impacts of feminist ethics and gender on the implementation of CSR initiatives. Filosofija Sociol. 2020, 31, 24-33. [CrossRef]

68. Cannas, M.; Sergi, B.S.; Sironi, E.; Mentel, U. Job satisfaction and subjective well-being in Europe. Econ. Sociol. 2019, 12, 183-196. [CrossRef]

69. D'Silva, J.L.; Samah, A.A. Holistic well-being of Japanese retirees in Malaysia. J. Int. Stud. 2018, 11, $95-103$. [CrossRef] 
70. Bilan, Y.; Mishchuk, H.; Samoliuk, N.; Yurchyk, H. Impact of Income Distribution on Social and Economic Well-Being of the State. Sustainability 2020, 12, 429. [CrossRef]

71. Churilova, E.; Salin, V.; Shpakovskaia, E.; Sitnikova, O. Influence of world social and economic indicators' interlinkage on the development of human potential. J. Int. Stud. 2019, 12, 79-99. [CrossRef] [PubMed]

(C) 2020 by the authors. Licensee MDPI, Basel, Switzerland. This article is an open access article distributed under the terms and conditions of the Creative Commons Attribution (CC BY) license (http://creativecommons.org/licenses/by/4.0/). 